\title{
Fenomena Kehidupan Remaja Yatim/Piatu di Dusun Sendang Biru Kabupaten Malang
}

\author{
Alfiana Yuli Efiyanti ${ }^{1}$, Esa Nur Wahyuni ${ }^{2}$ \\ UIN Maulana Malik Ibrahim Malang ${ }^{1,2}$ \\ Email: Alfi_huda@pips.uin-malang.ac.id ${ }^{1}$,esanw@uin-malang.ac.id ${ }^{2}$
}

\begin{abstract}
:
Young generation, especially teenagers, plays a very important role in the nation's sustainability. However, it becomes hard situation for orphan teenagers as they live in abnormal situations. In Sendang Biru, Sumbermanjing Wetan Malang, orphan teenagers experience problems that occur due to their orphan status. There are various social problems, that relating to economic and psychological problems. Continuously attention and assistance has been provided by the community through the social community "An Nisa". However, because the assistance is short-term and momentary, it only touches a small number of problems faced, and has not touched other psychological and social domains. We strongly recommend Sendang Biru community, government and higher education institutions to develop long-term programs that can solve the whole problems of orphan teenagers in Sendang Biru.
\end{abstract}

Keyword: sendang biru, orphan teenagers

Received February 09, 2019; Revised March 05, 2019; Accepted April 01, 2019

How to Cite: Efiyanti, A. Y., \& Wahyuni, E. N. (2019). Fenomena Kehidupan Remaja Yatim/Piatu di Dusun Sendang Biru Kabupaten Malang. JKI (Jurnal Konseling Indonesia), 4(2), 48-56.

This is an open access article distributed under the Creative Commons 4.0 Attribution License, which permits unrestricted use, distribution, and reproduction in any medium, provided the original work is properly cited. @2019 by author and Universitas Kanjuruhan Malang.

\section{PENDAHULUAN}

Anak-anak remaja merupakan generasi penerus yang kelak akan berperan penting pada berlangsungnya tatanan kehidupan. Betapa pentingnya peran remaja, maka tumbuh kembangnya perlu mendapat perhatian dari berbagai pihak. Diharapkan anak-anak remaja nantinya akan berkembang menjadi orang dewasa yang sehat secara fisik dan psikis sehingga mampu bertanggungjawab terhadap keberlangsungan bangsanya. Tumbuh kembang anak dapat ditinjau dari dua aspek yaitu pertumbuhan fisik dan non fisik. Pertumbuhan fisik erat kaitannya dengan pertumbuhan biologis. Pertumbuhan ini dapat diamati dengan mudah karena tampak perubahan bentuk fisik pada anak-anak seiring dengan bertambahnya usia. Sedang dari aspek non fisik perkembangan anak terletak pada kematangan sikap dan perilakunya. Perlu kecermatan dan kelengkapan instrument tertentu untuk mengamati perkembangan non fisik anak. Perkembangan non fisik berkaitan erat dengan perkembangan kejiwaan anak. Apabila salah satu atau kedua aspek pertumbuhan anak terganggu maka dapat dikhawatirkan anak tidak dapat menghadapi masa dewasanya dengan sempurna. Sehingga perhatian terhadap pertumbuhan anak harus memperhatikan keseimbangan kedua aspek tersebut.

Pada kondisi normal, proses pertumbuhan anak merupakan bagian dari keluarga yang pemenuhan kebutuhannya berada langsung dibawah tanggung jawab orang tua. Namun demikian pada kondisi-kondisi tertentu atau pada kondisi yang tidak normal, anak tidak lagi memperoleh semua yang dibutuhkan tersebut 
dari orang tuanya. Salah satu kondisi tidak normal dialami oleh anak-anak yatim/piatu yang tidak memiliki salah satu atau kedua orang tuanya. Anak-anak yatim/piatu tidak lagi memperoleh pemenuhan kebutuhan yang utuh di dalam masa pertumbuhannya karena tidak ada lagi orang tua yang secara alami melindungi dan memenuhi kebutuhannya. Untuk menjaga keberlangsungan tumbuh kembang anak, kebutuhan anak yatim/piatu ini harus tetap terpenuhi. Perlu adanya keterlibatan dari banyak pihak agar anak-anak yatim/piatu tetap berkembang secara normal meskipun sedang berada pada situasi yang tidak normal. Selain Negara sesuai dengan amanat UUD 1945, masyarakat sekitar juga dapat memberikan kontribusi penting bagi proses perkembangan anak yang telah ditinggalkan orang tuanya.

Di dusun Sendang Biru Kecamatan Sumber Manjing Wetan Kabupaten Malang, keberadaan anak yatim/piatu disebabkan oleh kondisi-kondisi yang khas. Penyebab dominan yang menjadikan anak-anak tersebut yatim/piatu adalah kecelakaan yang menimpa ayah ketika sedang bekerja di laut. Namun, ada pula beberapa penyebab lain kematian salah satu orang tua, seperti sakit dan kecelakaan lalu lintas. Dusun Sendang Biru adalah dusun yang lokasinya di tepi pantai selatan kabupaten Malang. Menurut data statistik kabupaten Malang, penduduk dusun Sendang Biru sebagian besar bekerja di sektor perikanan.

Keberadaan anak-anak yatim/piatu menjadi perhatian masyarakat dusun Sendang Biru. Melalui jamaah pengajian An Nisa, anak-anak ini memdapatkan santunan secara rutin 3 bulan sekali. Jama'ah pengajian An Nisa adalah kelompok pengajian yang beranggotakan Ibu-ibu dusun Sendang Biru dengan latar belakang pekerjaan mayoritas sebagai pedagang dan pengolah hasil laut. Jamaah ini melakukan pertemuan rutin satu minggu sekali dan pada peringatan-peringatan hari besar keagamaan. Perhatian kepada anak yatim/piatu diberikan oleh jamaah ini secara berkala dalam bentuk uang saku dan bingkisan yang berupa alat-alat kebutuhan sekolah. Selama ini jamaah belum memberi bantuan yang bersifat jangka panjang misalnya dalam bentuk pelatihan ataupun bantuan pendidikan.

Artikel ini disusun berdasarkan sebuah penelitian, yang bertujuan untuk mengeksplorasi secara mendalam fenomena kehidupan anak-anak yatim/piatu di dusun Sendang Biru. Agar diperoleh gambaran yang jelas, maka subyek yang dipelajari dikelompokkan dan dipilih salah satu dari kelompok tersebut. Kelompok yang dipilih adalah kelompok anak-anak yang masuk pada kategori remaja, yakni yang berumur 12 - 18 tahun, dimana kelompok tersebut sedang mengalami perubahan-perubahan, baik secara fisik maupun psikologi. Perubahan-perubahan pada diri remaja diawali dengan perubahan secara fisik. Menurut (Bilodeau, 2001) perubahan secara fisik dan hormon-hormon pada remaja menghasilkan perubahan reaksi kimia secara terus menerus dan menyebabkan perubahan fisik yang sangat cepat dan tidak terkontrol. Reaksi-reaksi kimia yang terjadi di dalam tubuh manusia dapat menentukan emosi seseorang. Pada remaja hal tersebut menghasilkan kondisi emosional yang tidak stabil (Wahyuni, 2012).

Selanjutnya studi difokuskan pada (1) kondisi ekonomi remaja yatim/piatu, (2) kondisi psikologis anakanak yatim/piatu (3) kontribusi masyarakat lokal terhadap keberlangsungan hidup remaja yatim/piatu.

\section{METODE PENELITIAN}

Penelitian dilakukan dengan menggunakan pendekatan kualitatif dengan jenis fenomenologi (Creswell \& Creswell, 2017). Dengan pendekatan ini, peneliti terlibat secara langsung dalam kehidupan subyek yang diteliti, yakni remaja yatim/piatu di Dusun Sendang Biru untuk mendalami fenomena-fenomena sosial yang terjadi pada subyek.

Jenis data yang digali berupa data primer dan data sekunder. Data primer diperoleh dengan cara melakukan wawancara mendalam dan observasi secara teliti dan menyeluruh. Informan kunci yang dijadikan sebagai sumber data primer yang diwawancarai terdiri dari 5 orang, yaitu tiga remaja yatim/piatu dan dua jamaah pengajian An Nisa. Sedangkan untuk memperkaya data diperlukuan informan pendukung yaitu para remaja yatim/piatu, perangkat desa dan anggota masyarakat lain. Observasi dilakukan secara natural dengan cara mengamati keseharian subyek yang diteliti agar diperoleh data yang akurat.

Data primer ini didukung dengan studi dokumentasi sebagai data sekunder. Dokumen yang dikaji diperoleh dari kantor Dusun Sendang Biru, kantor Desa Tambak Rejo dan kantor Kecamatan Sumber Manjing Wetan. Data diolah dengan menggunakan 4 langkah. Langkah pertama pengumpulan data. Setelah data terkumpul, dilakukan reduksi, dengan mengeliminir data-data yang tidak diperlukan dalam penelitian ini. Selanjutnya data disajikan dan disimpulkan. Untuk menjaga validitas data, maka trianggulasi diterapkan dalam penelitian ini, baik, trianggulasi sumber maupun trianggulasi pada teknik pengumpulan data. 


\section{HASIL}

\section{Deskripsi Dusun Sendang Biru}

Dusun Sendang Biru merupakan daerah pesisir yang terletak di sebelah selatan kota Malang. Jarak Dusun Sendang Biru dari Kota Malang sekitar 67 kilometer dan diperlukan waktu sekitar 2-2,5 jam untuk sampai ke lokasi tersebut. Secara administrasi, dusun sendang biru masuk dalam wilayah desa Tambakrejo kecamatan Sumbermanjing Wetan kabupaten Malang Jawa Timur. Dari sisi geografis, dusun Sendang Biru posisi yang berada pada ketinggian $75 \mathrm{~m}$ dari laut dan memiliki iklim cerah dengan curah hujan yang cukup tinggi, yakni rata-rata $\pm 2400 \mathrm{~mm}$. Curah hujan yang cukup tinggi ini mendukung pertanian di sekitar dusun Sendang Biru meskipun lahan mata pencaharian utama warga dusun ini bukanlah pertanian.

Selain potensi alam berupa curah hujan yang cukup tinggi dan pertanian, potensi alam berupa laut yang membentang di sepanjang pesisir Sendang Biru juga merupakan modal alam terbesar bagi pertumbuhan dan perkembangan ekonomi masyarakat. Dalam satu hari rata-rata sebanyak 80 ton ikan hasil tangkapan nelayan Sendang Biru terjual di tempat pelelangan ikan (TPI) yang dibangun oleh pemerintah sejak tahun 1980. TPI tersebut menggerakkan roda perekonomian masyrakat setempat.

Potensi alam lain yang bisa dikembangkan selain hasil laut adalah bidang pariwisata pantai. Pesisir Sendang biru yang mulai dibuka pertama kali pada tahun 1970 ini menyajikan pemandangan pantai yang biru dan tenang. Ombak tidak terlalu besar karena lokasi yang berhadapan dengan pulau Sempu. Pulau Sempu inilah yang melindungi pesisir Sendang Biru dari ombak besar pantai selatan, sehingga aman bagi wisatawan. Selat Sempu yang hanya berjarak sekitar 4 kilometer cocok digunakan untuk berwisata perahu atau olahraga air. Sedangkan Pulau Sempu sendiri merupakan Cagar Alam yang memiliki danau tawar di dalam hutannya.

Dengan adanya dua daya Tarik yakni TPI dan wisata pantai, maka dusun Sendang Biru tidak pernah sepi pengunjung. Mayoritas wisatawan yang berlibur ke pantai-pantai lain di sepanjang Jalur Lintas Selatan menyempatkan datang ke Sendang Biru untuk berbelanja ikan dengan harga yang relative lebih murah. Hasil laut andalan yang dapat ditemui di Sendangbiru adalah tuna. Namun juga ada jenis lain tergantung dari hasil tangkap nelayan, antara lain ikan pelagis yaitu lemurung, layang, teri, tongkol, kembung, dan cumi-cumi. Sedangkan untuk jenis damersal antara lain pari, kerapu, kakap putih, kakap merah dan bawal putih.

\section{Fenomena Remaja Yatim/Piatu di Dusun Sendang Biru}

Dusun Sendang Biru yang telah digambarkan pada subbab diatas menyimpan berbagai dinamika kehidupan. Data desa menunjukkan bahwa sebagian besar penduduk dusun bekerja di bidang kelautan. Masyarakat yang menekuni jenis pekerjaan ini dibedakan menjadi dua, yakni orang-orang bekerja di laut dan yang bekerja di darat. Di dalam dinamika kehidupan masyarakat, tidak hanya orang dewasa, para anak-anak dan remaja sangat akrab dengan aktivitas masyarakat pesisir.

Sebuah fenomena menarik ada pada kehidupan masyarakat pesisir dusun Sendang Biru, yakni keberadaan anak-anak remaja yatim/piatu. Definisi yatim/piatu secara terminology dikemukakan oleh Quraish Syaikh Mahmud Syaltut yang mendefinisikan yatim piatu sebagai anak yang ditinggal mati oleh orang tuanya atau salah satu dari orang tua (Syaltut, 1991). Definisi lain dikemukakan oleh Muhsin yang menyatakan bahwa yatim piatu adalah anak yang masih kecil, lemah, belum bisa mandiri, dan ditinggal mati oleh kedua orang tuanya. Status yatim/piatu yang disandang oleh para remaja yatim/piatu di dusun Sendang Biru, sebagian besar disebabkan oleh kecelakaan yang dialami oleh orang tua mereka (ayah) atau hilang ketika menangkap ikan di laut (Muhsin, 2003). Sedangkan sebagian lain karena sakit (salah satu dari orang tua atau keduanya).

Total jumlah remaja yatim/piatu di dusun Sendang Biru sebanyak 24 orang. Tabel 1 di bawah menggambarkan keberadaan remaja yatim/piatu dan penyebab mereka menjadi yatim/piatu.

Tabel 1. Remaja Yatim/Piatu Berdasarkan Jenis Kelamin dan Penyebab Menjadi Yatim/Piatu

\begin{tabular}{ccccc}
\hline & Jenis Kelamin & \multicolumn{3}{c}{ Penyebab Yatim/Piatu } \\
\hline Laki-laki & Perempuan & $\begin{array}{c}\text { Orang tua } \\
\text { kecelakaan/hilang } \\
\text { di laut }\end{array}$ & $\begin{array}{c}\text { Orang tua } \\
\text { sakit }\end{array}$ & $\begin{array}{c}\text { Orang tua } \\
\text { kecelakaan di } \\
\text { darat }\end{array}$ \\
\hline $21 \%$ & $79 \%$ & $50 \%$ & $29 \%$ & $21 \%$ \\
\hline
\end{tabular}

Sumber: data, diolah (2018)

Dari segi usia, para anak-anak yatim/piatu tersebut berada pada usia 12-18 tahun. Oleh sebab itu mereka dikategorikan sebagai anak remaja, atau biasa disebut sebagai remaja saja. Remaja atau yang disebut 
dengan adolescence, secara bahasa berasal dari kata dalam bahasa Belanda "adolescere" yang berarti remaja dan bermakna tumbuh menjadi dewasa. Pengertian menjadi dewasa merujuk pada pertumbuhan mencapai kematangan dalam aspek fisik, emosi, sosial, maupun kognitif. Secara kronologis usia, remaja adalah individu yang berada pada usia antara 12-21 tahun, dengan pembagian remaja awal berada pada usia 12-15 tahun, remaja tengah usia 15-18 tahun, dan remaja akhir berada usia 18-21 tahun (Hurlock, 2001). Dilihat dari rentang usia, menunjukkan bahwa remaja adalah masa peralihan dari usia anak-anak menuju usia dewasa (Mönks et al., 1985).

Sedangkan dari segi pendidikan formal, remaja yatim/piatu dusun Sendang Biru sedang menduduki jenjang sekolah tingkat SD/MI, SMP/MTs dan SMA/MA/SMK. Beberapa anak tidak melanjutkan sekolah dan hanya berhenti pada jenjang sekolah dasar karena alasan tidak mampu. Tabel 2 di bawah menggambarkan usia dan tingkat pendidikan remaja yatim/piatu di dusun Sendang Biru.

Tabel 2. Remaja Yatim/Piatu Berdasarkan Usia dan Tingkat Pendidikan

\begin{tabular}{cccccc}
\hline & Usia & \multicolumn{3}{c}{ Tingkat Pendidikan Formal } \\
\hline $12-15$ & $16-18$ & SD/MI & SMP/MTs & $\begin{array}{c}\text { SMA/MA/ } \\
\text { SMK }\end{array}$ & $\begin{array}{c}\text { Tidak/Putus } \\
\text { Sekolah }\end{array}$ \\
\hline $90 \%$ & $10 \%$ & $12 \%$ & $80 \%$ & $4 \%$ & $4 \%$ \\
\hline
\end{tabular}

Sumber: data, diolah (2018)

Pengasuhan remaja yatim/piatu secara langsung oleh salah satu orang tua, jika yang meninggal adalah ayah/ibu. Namun pada beberapa kasus, meskipun salah satu orang tua masih ada, anak diasuh oleh kerabat lain seperti kakak, nenek/kakek, paman/bibi. Jika sudah ditinggal oleh kedua orang tua, maka pengasuhan diambil alih oleh kerabat atau orang lain yang bukan kerabat. Gambaran mengenai pengasuh/wali remaja yatim/piatu dapat dilihat pada tabel 3 di bawah ini.

Tabel 3. Pengasuhan Remaja Yatim/Piatu

\begin{tabular}{lc}
\hline \multicolumn{1}{c}{ Pengasuh/wali remaja yatim/piatu } & Jumlah (\%) \\
\hline Orang tua yang masih ada (ayah/ibu) & $63 \%$ \\
Kerabat (kakak, paman/bibi, kakek/nenek) & $29 \%$ \\
Orang lain yang bukan kerabat & $8 \%$ \\
\hline
\end{tabular}

Sumber: data, diolah (2018)

Secara fisik, para remaja tersebut tampak seperti remaja pada umumnya di dalam menjalankan aktifitas sehari-hari. Selain belajar di sekolah formal aktifitas sehari-hari remaja yatim/piatu adalah membantu wali atau pengasuh mereka dalam mengurus rumah tangga, membantu mengurus usaha perdagangan dan usaha pencarian ikan. Sebagian dari mereka bahkan bekerja untuk memperoleh penghasilan karena ketidakmampuan wali dari sisi ekonomi. Karena masih berusia belia tentu para remaja tersebut belum memiliki keterampilan dan pengalaman yang memadai. Dengan demikian, maka pekerjaan yang diperoleh pun termasuk pada jenis nonskill dengan pendapatan yang relative kecil. Jenis pekerjaan yang sering dilakukan oleh remaja yatim/piatu yakni sebagai tenaga penguras perahu, pengecat perahu dan pengangkut ikan.

Meskipun secara visual tampak seperti remaja-remaja lain, namun demikian dalam pertumbuhannya, para remaja yatim/piatu memiliki keterbatasan-keterbatasan pada beberapa aspek. Selain memiliki keterbatasan secara ekonomi remaja yatim di Sendang Biru juga mengalami problema secara psikologis.

\section{Kondisi Perekonomian Remaja Yatim/Piatu}

Bagi remaja yatim/piatu yang telah ditinggalkan ayah, kepergian ayah akibat kecelakaan saat bekerja menangkap ikan di laut, menyebabkan mereka mengalami kesulitan memenuhi kebutuhan fisik. Banyak diantara remaja-remaja tersebut hanya bergantung kepada saudara/orang lain yang peduli kepada nasib mereka. Bagi mereka yang kehilangan ibupun beban ekonomi tetap dirasakan karena perhatian ayah terhadap anak terbagi dengan keharusan bekerja. Sedangkan bekerja bagi kaum nelayan berarti ke laut, dan membutuhkan waktu paling sedikit satu hari, paling lama 1 bulan tergantung jenis perahu. Pemenuhan kebutuhan anak selama ditinggalpun terbengkalai.

Sebagian remaja tertuntut untuk memenuhi kebutuhan hidup dan pendidikannya sendiri. Bahkan pada beberapa remaja yatim/piatu mereka bekerja sebagai tulang punggung keluarga. Pekerjaan yang dilakukan 
bervariasi, namun semua masuk ke dalam pekerjaan kasar atau nonskill. Jenis pekerjaan tersebut yang paling sering dilakukan antara lain menguras perahu, kuli angkut dan pekerjaan serabutan. Berikut lebih jelasnya terdapat pada gambar 1 di bawah ini menggambarkan prosentase remaja yatim/piatu yang tidak bekerja, bekerja dan jenis pekerjaan yang ditekuni.

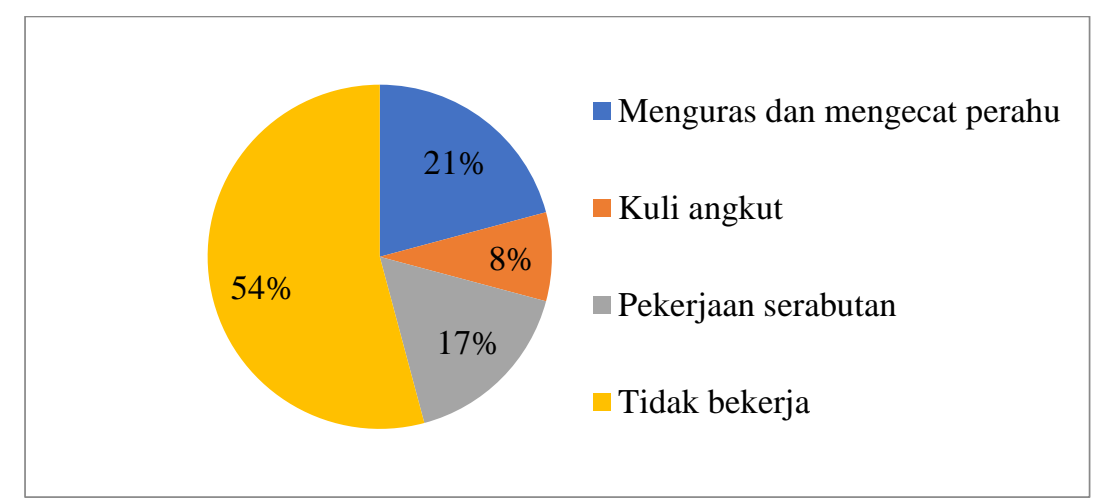

Gambar 1. Jenis pekerjaan remaja yatim/piatu dusun Sendang Biru

\section{Kondisi Psikologis Remaja Yatim/Piatu}

Meskipun secara visual tampak seperti remaja pada umumnya, remaja yatim/piatu di dusun Sendang Biru mengalami problema secara psikologis. Fenomena tersebut dipengaruhi oleh beberapa faktor yang didominasi oleh perasaan memiliki status sebagai remaja yang ditinggal oleh ayah atau ibu, atau keduanya. Hal ini menyebabkan mereka merasa berbeda dari remaja lain di sekitarnya yang masih memiliki orang tua lengkap.

Secara psikologi, problema yang dihadapi oleh remaja yatim piatu Sendang Biru adalah tidak percaya diri, ragu dengan masa depan, dan menyerah kepada kondisi yang ada. Hal tersebut dapat diindikasikan bahwa remaja yatim/piatu kurang memiliki rasa optimis. Kurangnya rasa optimis dapat menyebabkan remaja mengalami hambatan dalam perkembangan kepribadian dan menyebabkan kesulitan mencapai masa depan yang cerah. Ditambah lagi status sebagai remaja yatim piatu mempengaruhi pandangan masyarakat disekitar yang cenderung under-estimate terhadap mereka.

\section{Kontribusi Masyarakat Lokal Terhadap Keberlangsungan Hidup Remaja Yatim/Piatu.}

Fenomena keberadaan anak-anak yatim piatu mendorong beberapa pihak untuk memberikan bantuan kepada anak-anak tersebut. Jamaah pengajian An Nisa' adalah salah satu dari kelompok masyarakat yang memberikan perhatian kepada anak-anak yatim/piatu di dusun Sendang Biru. Jamaah ini beranggotakan wanita nelayan dusun Sendang Biru. Wanita nelayan adalah suatu istilah yang digunakan untuk menyebut para wanita yang hidup di lingkungan nelayan, baik sebagai istri maupun anak atau keluarga dari nelayan pria, atau wanita bukan keluarga nelayan yang bekerja di lingkungan nelayan. Wanita nelayan umumnya ikut terlibat dalam aktivitas mencari nafkah untuk keluarganya selain mengurus pekerjaan rumah tangga, meskipun tidak terlibat secara langsung dalam kegiatan mencari ikan di laut. Mereka biasa bekerja sebagai pengumpul kerang-kerangan, pengolah hasil ikan tangkap, pedagang ikan dan pemilik/penjaga warung di pesisir. Bahkan beberapa wanita nelayan ikut aktif memperbaiki peralatan tangkap ikan (Indrawasih, 2015).

Ada 60 wanita nelayan yang tergabung sebagai anggota jamaah pengajian An Nisa'. Kelompok masyarakat ini berkumpul satu minggu sekali untuk melaksanakan aktifitas-aktifitas keagaamaan, dan membahas persoalan-persoalan sosial kehidupan. Berdiri sejak tahun 2012, jamaah pengajian ini menggagas program bantuan atau santunan kepada anak-anak yatim di lingkungan mereka. Program santunan dilaksanakan 3 kali dalam setahun. Kegiatan tersebut juga mengundang jamaah pengajian lain dan anggota masyarakat yang memiliki kepedulian dan bermaksud ikut serta dalam penyantunan anak-anak yatim/piatu. Kegiatan ini dari tahun ke tahun selalu disambut dengan baik oleh masyarakat dusun Sendang Biru. Tampak bahwa pada saat kegiatan tersebut dilaksanakan, berbagai lapisan masyarakat menghadiri dan ikut serta memberikan santunan. Mereka adalah dari kalangan pemilik perahu, pengambek, pedagang dan pengolah hasil laut. Bentuk kegiatan santunan dimulai dengan ceramah atau mempelajari topik-topik keislaman, kemudian dilanjutkan dengan pemberian dana santunan secara langsung kepada anak-anak yatim oleh para pemberi santunan. 


\section{PEMBAHASAN}

Dusun Sendang Biru yang secara geografis dan kelembagaan merupakan bagian dari desa Tambak Rejo Kecamatan Sumber Manjing Wetan Kabupaten Malang menyimpan banyak kekayaan alam berupa laut beserta dengan segenap biota di dalamnya. Selain itu pesisir dan pantainya menyajikan potensi pariwisata yang mejadikannya sebagai salah satu destinasi wisata pantai selatan. Dalam dinamika kehidupan masyarakat dusun Sendang Biru, terdapat fenomena menarik yakni keberadaan remaja yatim/piatu yang harus berjuang melanjutkan kehidupan dengan berbagai keterbatasan yang dimiliki.

Remaja yatim/piatu di dusun Sendang Biru adalah individu yang sedang berada pada tahap perkembangan dari masa kanak-kanak menuju masa dewasa. Masa perkembangan remaja adalah masa di mana individu sedang berusaha untuk mencari identitas diri. Keberhasilan remaja mencari identitas diri akan memberikan dampak yang positif bagi perkembangan kepribadian remaja, sebaliknya kegagalan menemukan identitas diri dapat menimbulkan ganguan bagi perkembangan remaja. Pada kondisi yang normal, masa remaja merupakan masa yang cukup rentan bagi perkembangan individu. Apalagi jika masa remaja dilalui di dalam kondisi yang tidak normal, yakni kondisi yatim/piatu.

Para ahli perkembangan menggambarkan masa ini adalah masa yang paling berat dalam perkembangan hidup manusia. Sebagaimana dikemukakan oleh Erikson, bahwa setiap tahap perkembangan manusia pasti mengalami berbagai macam tantangan dan permasalahan yang dinamis, namun masa remaja adalah masa yang paling berat dalam tahap perkembangan manusia (Erikson \& Erikson, 1998). Sedangkan ahli perkembangan remaja Stanley Hall menggambarkan masa remaja sebagai "storm and stress", yaitu fase kehidupan manusia yang penuh dengan badai dan tekanan (Arnett, 2006). Gambaran tersebut dikemukakan oleh Stanley Hall berdasarkan hasil penelitiannya yang menunjukkan bahwa pada usia remaja individu mengalami perubahan-perubahan yang dapat menyebabkan remaja mengalami tekanan sehingga menimbulkan problema emosional (Arnett, 2006).

Pada diri remaja yatim piatu, potensi gangguan psikologis dan kepribadian cukup besar. Kondisi remaja yatim piatu yang tidak memiliki orang tua, dapat menimbulkan permasalahan seperti, merasa berbeda dari orang lain, merasa ada yang kurang dalam dirinya, serta adanya perlakuan yang berbeda dari lingkungan dapat memicu munculnya tekanan emosional yang pada akhirnya akan menghambat kepribadiannya. Hambatan kepribadian tersebut dapat berbentuk rendahnya rasa percaya diri, menutup diri dari pergaulan sekolah, atau berperilaku agresif (Suseno, 2013).

Beberapa hasil penelitian secara konsisten menunjukkan bahwa hilangnya pengasuhan yang berkualitas dan kehangatan kasih sayang orang tua dapat menyebabkan depresi dan putus asa menghadapi hidup pada anak-anak dan itu dapat berlanjut hingga dewasa (Taukeni, 2015).

Secara ekonomi, remaja yatim/piatu dusun Sendang Biru yang ditinggal ayah cenderung berusaha untuk bekerja memenuhi kebutuhan diri dan keluarga. Kurangnya keterampilan hidup yang memadai menyebabkan banyak dari mereka yang menjadi pekerja kasar di pesisir dan di tempat pelelangan ikan (TPI). Dengan demikian mereka memiliki posisi bargaining yang lemah. Tanpa perlindungan, remaja yatim/piatu yang bekerja memiliki perlakuan yang sama dengan pekerja-pekerja dewasa lainnya. Tidak ada perhatian khusus bahwa sejatinya berdasarkan usia, mereka masih masuk dalam kategori anak-anak yang seyogyanya secara hukum terlindungi. Sebagaimana (Prajnaparamita, 2018), Pada hakekatnya anak tidak boleh bekerja karena waktu mereka selayaknya dimanfaatkan untuk belajar, bermain, bergembira, berada dalam suasana damai, mendapatkan kesempatan dan fasilitas untuk mencapai cita-citanya sesuai dengan perkembangan fisik, psikologi, intelektual dan sosialnya. Namun pada kenyataannya banyak anak-anak di bawah usia 18 tahun yang telah terlibat aktif dalam kegiatan ekonomi, menjadi pekerja anak antara lain di sektor industri dengan alasan tekanan ekonomi yang dialami orang tuanya ataupun faktor lainnya.

Selain masalah ekonomi, kondisi tidak memiliki ayah/ibu yang dialami oleh remaja yatim/piatu di dusun Sendang Biru menyebabkan mereka mengalami masalah psikologi seperti tidak percaya diri, menyerah dengan kondisi yang ada, tidak berani memiliki cita-cita, dan self esteem yang rendah. Berkembangnya fisik remaja yang sangat cepat juga menyebabkan secara fisik mereka hampir menyamai orang dewasa. Terhadap kondisi demikian, masyarakat memiliki pandangan yang berbeda. Masyarakat mengharapkan remaja memenuhi tanggungjawab orang dewasa. Padahal, disisi lain perkembangan fisik yang sangat cepat tidak diikuti perkembangan psikis remaja yang matang, sehingga terjadi kesenjangan yang sangat lebar. Ketika harapan masyarakat dan lingkungan sosial menjadi tekanan, maka secara tidak sengaja masyarakat dan lingkungan telah menciptakan dogma-dogma yang absolut, tidak realistis. Hal ini menyebabkan remaja seringkali mengalami problema emosional. Apa bila remaja tidak mampu memenuhi tuntutan masyarakat akan menimbulkan konflik pada diri remaja. Ketidak mampuan remaja memenuhi tuntutan masyarakat menyebabkan tekanan emosional yang dapat mengancam harga diri dan mengganggu perkembangan kepribadian. 
Problema psikologi tersebut dapat mempengaruhi perkembangan kepribadian remaja yatim piatu. Untuk dapat tumbuh menjadi individu-individu yang tangguh pada saat dewasa para remaja yatim/piatu hendaknya memiliki kesadaran sejak dini akan potensi yang terdapat di dalam diri sendiri, dan potensi yang ada di lingkungannya. Dengan kata lain remaja harus memiliki rasa optimis di dalam jiwanya. Rasa optimis yang dimiliki oleh remaja yatim/piatu dusun Sendang Biru rendah karena kondisi mereka. Padahal optimisme merupakan suatu harapan yang kuat dan berpikir bahwa hal-hal yang diinginkan akan berjalan dengan baik meskipun terjadi kemunduran dan frustrasi. Sebagai nilai etika, optimisme adalah gagasan manusia selalu memiliki yang terbaik dan mendapatkannya dengan cara yang sama, meskipun beberapa situasi selalu sulit untuk menemukan yang baik dan mendapatkan hasil terbaik. Dari sudut pandang kecerdasan emosional, optimisme adalah sikap yang membuat orang tegar dari jatuh ke wajah apatis, putus asa atau depresi kesulitan.

Individu yang memiliki sikap optimis jarang menderita depresi dan lebih mudah mencapai kesuksesan dalam hidup, memiliki kepercayaan, dapat berubah ke arah yang lebih baik, adanya pemikiran dan kepercayaan mencapai sesuatu yang lebih baik, dan selalu berjuang dengan kesadaran penuh (Robins \& John, 1997). Diperkuat dengan (McGinnis \& Lee, 1995) yang menyatakan orang-orang optimis jarang merasa terkejut oleh kesulitan. Mereka merasa yakin memiliki kekuatan untuk menghilangkan pemikiran negatif, berusaha meningkatkan kekuatan diri, menggunakan pemikiran yang inovatif untuk menggapai kesusksesan, dan berusaha gembira, meskipun tidak dalam kondisi bahagia.

Individu yang optimis akan berusaha menggapai pengharapan dengan pemikiran positif, yakin akan kelebihan yang dimiliki (Scheier \& Carver, 1985). Individu optimisme biasa bekerja keras menghadapi stress dan tantangan sehari-hari secara efektif, berdoa dan mengakui adanya faktor keberuntungan dan faktor lain yang turut mendukung keberhasilannya.

Individu yang optimis memiliki impian untuk mencapai tujuan, berjuang dengan sekuat tenaga, dan tidak ingin duduk berdiam diri menanti keberhasilan yang akan diberikan oleh orang lain. Individu optimis ingin melakukan sendiri segala sesuatu dan tidak ingin memikirkan ketidakberhasilan sebelum mencoba. Individu yang optimis berpikir yang terbaik, tetapi juga memahami untuk memilih bagia masa yang memang dibutuhkan sebagai ukuran untuk mencari jalan.

Hasil penelitian ini juga menunjukkan bahwa perhatian dan bantuan yang diberikan kepada remaja yatim/piatu lebih diutamakan pada aspek ekonomi, yakni finansial atau penghidupan, seperti sandang, pangan, dan papan. Bantuan dan perhatian yang diberikan oleh masyarakat itupun masih bersifat insidentil dan lebih berfokus pada hal yang bersifat fisik. Sedangkan perhatian yang menyentuh ke ranah psikologi masih kurang. Bantuan yang bersifat jangka panjang untuk pemberdayaan remaja yatim piatu belum dilaksanakan.

Aspek-aspek sosial lain juga kurang mendapatkan prioritas seperti pendidikan dan kesehatan. Kesejahteraan psikososial terhadap remaja yatim/piatu tersebut perlu diperhatikan sedini mungkin, terutama untuk menumbuhkan rasa optimis dalam diri mereka cenderung diabaikan. Hal ini disebabkan kesejahteraan sosial merupakan faktor penting bagi anak-anak untuk tumbuh dan berkembang dengan baik. Ketika anakanak tidak sejahtera secara psikososial, mereka akan berpotensi mengalami berbagai masalah kepribadian yang dapat merugikan masa depan mereka dan masyarakat.

Pada dasarnya, untuk keberlangsungan masa depan, remaja yatim/piatu dusun Sendang Biru memiliki potensi untuk berkembang dengan baik, tentu saja dengan intervensi berbagai pihak. Dengan pengkajian yang mendalam, secara internal diketahui bahwa (1) remaja yatim/piatu dusun Sendang Biru adalah generasi muda yang memiliki kesempatan untuk berkembang dan sukses dalam hidupnya jika mendapatkan pengasuhan dan bimbingan yang tepat, (2) remaja yatim piatu di Sendang Biru memiliki potensi positif yakni tabah, sabar, dalam menjalani kehidupan dan pekerja keras untuk memenuhi kebutuhan hidup dirinya dan terkadang juga keluarganya.

Sedangkan secara eksternal beberapa situasi dapat mendorong tumbuh kembang remaja yatim/piatu dengan maksimal, yaitu (1) adanya perhatian dan motivasi yang kuat pada diri wali untuk mengasuh anak yatim sampai mereka mandiri, (2) dukungan dari masyarakat terutama jamaah pengajian An-Nisa' yang memiliki kepedulian terhadap keberadaan anak yatim piatu yang ada di Sendang Biru, (3) perhatian aparat pemerintah khususnya kepala desa Dusun Sendang Biru terhadap upaya penyejahteraan anak yatim piatu di dusun sendang Biru, (4) potensi alam dusun Sendang Biru yang dapat dimanfaatkan secara maksimal untuk peningkatan kesejahteraan remaja yatim/piatu di dusun Sendang Biru. Fenomena remaja yatim/piatu di dusun Sendang Biru beserta dinamika kehidupannya dapat digambarkan secara utuh pada gambar di bawah ini. 


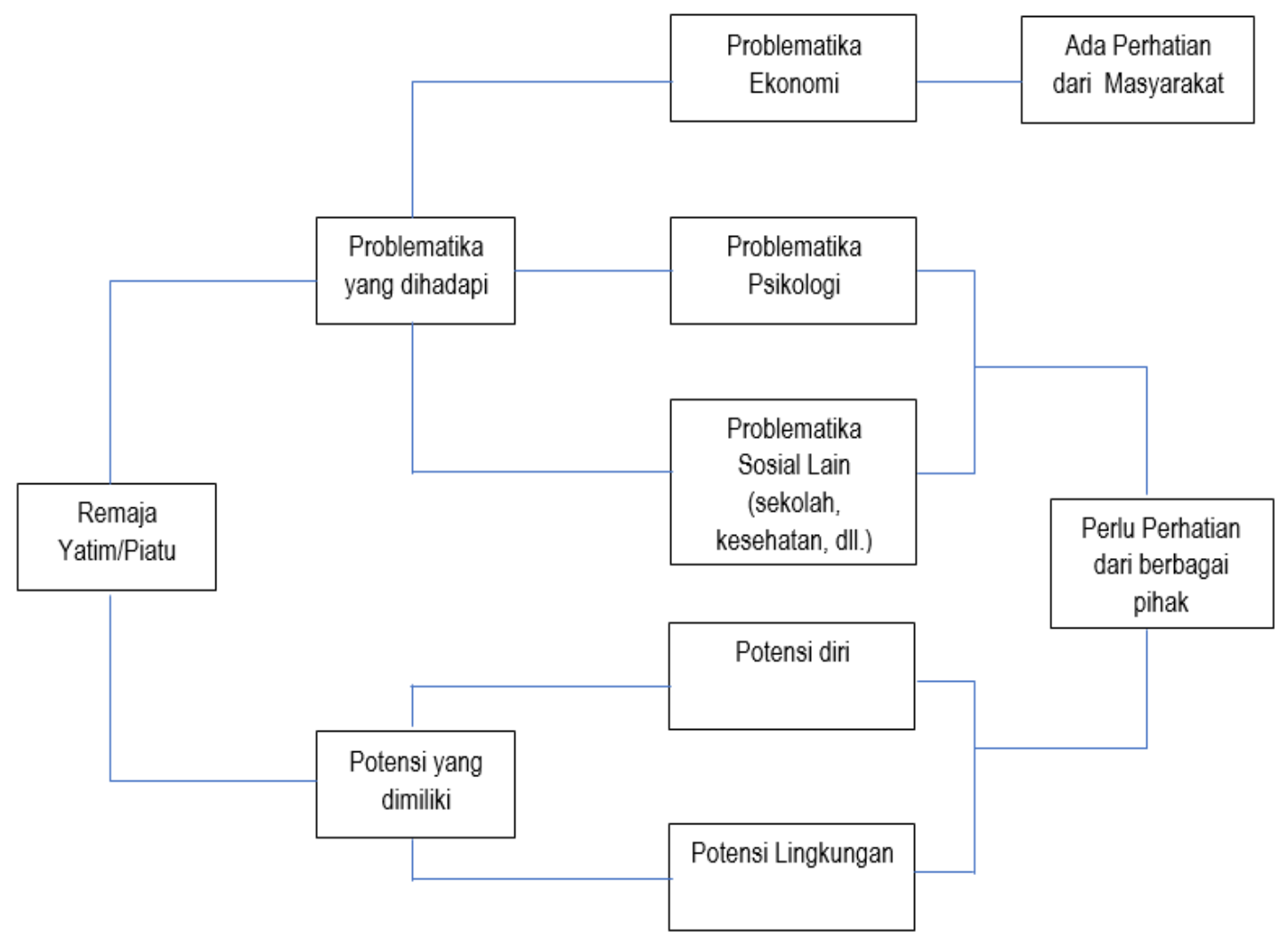

Gambar 2. Fenomena Remaja Yatim/Piatu Dusun Sendang Biru

\section{SIMPULAN DAN SARAN}

\section{Simpulan}

Dusun Sendang Biru yang terletak di desa Tambak Rejo Kecamatan Sumber Manjing Kabupaten Malang menyimpan fenomena-fenomena yang sangat menarik. Disamping kekayaan alam yang melimpah, dusun ini menyimpan potensi sumber daya manusia yang luar biasa. Diantaranya adalah para remaja yatim/piatu yang menjadi tumpuan harapan masa depan. Ada beberapa hal yang perlu diperhatikan dari kondisi remaja yatim/piatu. Secara ekonomi, keterbatasan-keterbatasan pemenuhan kebutuhan hidup dialami oleh para remaja ini, sehingga menyebabkan mereka terpaksa bekerja. Tanpa keterampilan yang memadai, pekerjaan yang diperoleh pun berjenis pekerjaan kasar atau non-skill. Sedangkan dari sisi psikologis, dapat diidentifikasi bahwa remaja yatim/piatu mengalami persoalan-persoalan yang tidak sederhana. Dibarengi dengan masa-masa pertumbuhan alamiah remaja yang rentan konflik kejiwaan, kondisi yatim/piatu menyebabkan fase remaja mereka juga mengalami problematika tersendiri.

Perhatian oleh masyarakat dusun Sendang Biru terhadap keberadaan anak-anak dan remaja yatim/piatu telah diberikan. Melalui jamaah pengajian An Nisa' santunan kepada anak-anak yatim/piatu dilakukan 3 bulan sekali. Namun bantuan yang diberikan terbatas pada bantuan keuangan dan bersifat insidental. Belum ada bantuan yang dapat berimbas jangka panjang dan menyentuh sisi kejiwaan anak. Padahal baik secara internal maupun eksternal, remaja yatim/piatu dusun Sendang Biru memiliki potensi yang tinggi untuk berkembang dengan dukungan-dukungan dari pihak lain.

\section{Saran}

Masyarakat dusun Sendang Biru terutama Jamaah An Nisa' hendaknya mengembangkan kepedulian dan perhatian yang telah mereka berikan selama ini kepada remaja yatim/piatu ke dalam bentuk dukungan yang tidak semata-mata bersifat financial dan sesaat. Diperlukan program-program bantuan yang memberikan dampak lebih panjang bagi para remaja yatim/piatu dan memperhatikan sisi sosial dan psikologis.

Pemerintah desa Tambakrejo yang secara administrative dan geografis menaungi dusun Sendang Biru hendaknya melakukan kerja sama dengan lembaga-lembaga lain misalnya lembaga pendidikan non formal 


\section{Jurnal Konseling Indonesia}

http://ejournal.unikama.ac.id/index.php/JKI

ISSN: Print 2475-888X - Online 2476-8901

untuk mengembangkan program-program pengembangan bagi remaja yatim/piatu, mengingat terbukanya potensi para remaja yatim/piatu untuk berkembang sangat tinggi.

Perguruan Tinggi sebagai lembaga pendidikan formal yang mengemban amanah tridarma hendaknya menggunakan hasil penelitian ini sebagai bahan rujukan untuk mengembangkan program-program penelitian dan pengabdian yang mengarah kepada pengembangan pendidikan dan pengembangan kejiwaan bagi remaja yatim/piatu dusun Sendang Biru.

\section{DAFTAR RUJUKAN}

Arnett, J. J. (2006). G. Stanley Hall's Adolescence: Brilliance and nonsense. History of Psychology, 9(3), 186.

Bilodeau, L. (2001). Responding to anger: a workbook. Hazelden Publishing.

Creswell, J. W., \& Creswell, J. D. (2017). Research Design: Qualitative, Quantitative, and Mixed Methods Approaches. Thousand Oaks, CA: Sage Publications.

Erikson, E. H., \& Erikson, J. M. (1998). The life cycle completed (extended version). WW Norton \& Company.

Hurlock, E. B. (2001). Developmental Psychology. New York: Tata McGraw-Hill Education.

Indrawasih, R. (2015). The Productive Role of Women In Several Indonesian Fishing Communities. Jurnal Masyarakat Dan Budaya, 17(2), 249-264.

McGinnis, J. M., \& Lee, P. R. (1995). Healthy People 2000 at mid decade. Jama, 273(14), 1123-1129.

Mönks, F. J., Knoers, A. M. P., \& Haditono, S. R. (1985). Psikologi Perkembangan: Pengantar dalam berbagai bagiannya. Yogyakarta: Gadjah Mada University Press.

Muhsin, M. K. (2003). Mari Mencintai Anak Yatim. Gema Insani.

Prajnaparamita, K. (2018). Perlindungan Tenaga Kerja Anak. Administrative Law \& Governance Journal, 1(2), 215-230.

Robins, R. W., \& John, O. P. (1997). The quest for self-insight: Theory and research on accuracy and bias in self-perception. In Handbook of personality psychology (pp. 649-679). Elsevier.

Scheier, M. F., \& Carver, C. S. (1985). Optimism, coping, and health: assessment and implications of generalized outcome expectancies. Health Psychology, 4(3), 219.

Suseno, M. N. (2013). Efektivitas pembentukan karakter spiritual untuk meningkatkan optimisme terhadap masa depan anak yatim piatu. Jurnal Intervensi Psikologi, 5(1), 1-24.

Syaltut, S. M. (1991). Metodologi Al-Qur'an. Solo: CV Ramadhani.

Taukeni, S. G. (2015). Orphan adolescents' lifeworlds on school-based psychosocial support. Health Psychology and Behavioral Medicine, 3(1), 12-24.

Wahyuni, E. N. (2012). Keefektifan teknik observasi diri dan mengubah dialog internal untuk meningkatkan kemampuan remaja mengelola marah. 